\title{
PENGUJIAN KERANGKA KERJA PEMERINGKATAN E-GOVERNMENT DI INDONESIA (PeGI): STUDI KASUS DI TINGKAT KEMENTERIAN
}

\author{
Darmawan Baginda Napitupulu \\ Pusat Penelitian Sistem Mutu dan Teknologi Pengujian Lembaga Ilmu Pengetahuan Indonesia \\ Kawasan Puspiptek Gd. 417, Serpong, Tangerang Selatan, Indonesia \\ No. Telp /HP: 081314060258 \\ E-mail: darwan.na70@gmail.com
}

Naskah dikirim tanggal 15 November 2016, direvisi tanggal 9 Maret 2017, diterima tanggal 11 April 2017

\section{TESTING E-GOVERNMENT RANKING FRAMEWORK IN INDONESIA (PeGI): CASE STUDY IN MINISTRY LEVEL}

\begin{abstract}
E-Government progress in Indonesia takes place since the existence of Inpres 3 of 2003 on national policy and strategy of e-government development. In that regulation, clearly regulated the responsibility of all central and regional government institutions to develop egovernment system as a form of electronic based public service. One of the strategies formulated by the government is to develop e-Government systematically through the realistic and measurable stages. In other words, the government wants to encourage increased use of Information and Communication Technology (ICT) in government institution through integral, balanced, and objective evaluation. Therefore, the government needs to perform the evaluation in order to measure the use of ICT in governance (a government institution). PeGI (eGovernment Ranking in Indonesia) is an event held periodically by the Ministry of Communications and Information Technology since 2007 with the objective to improve the effectiveness and efficiency of application of ICT in government institutions. The dimensions of PeGI ratings cover the aspects: policy, institutional, infrastructure, applications, and planning. This research purpose is to test empirically the framework of PeGI that has been used to measure the use of ICT which the PeGI itself consists of 5 dimensions and 35 attributes assessment. In other words, we want to know whether PeGI framework is still relevant today, especially at the ministerial level, consider that the development of ICT is rapid and dynamic. The method used is quantitative with factor analysis approach. The results showed that all the attributes are valid and could represent each dimension of the PeGI rating: policies, institutions, infrastructure, applications, and planning. Therefore, PeGI framework is still relevant to use for assessing e-Government implementation, especially in ministry level.
\end{abstract}

Keywords: PeGI, e-Government, framework, testing, ICT.

Abstrak. Geliat e-Government di Indonesia bergulir sejak adanya Inpres No. 3 Tahun 2003
tentang kebijakan dan strategi nasional pengembangan e-Government. Di dalam regulasi
tersebut jelas diatur kewajiban seluruh lembaga pemerintah baik pusat maupun daerah untuk
mengembangkan sistem e-Government sebagai bentuk pelayanan publik yang berbasis
elektronik. Salah satu strategi yang dirumuskan pemerintah adalah melaksanakan
pengembangan $e$-Government secara sistematik melalui tahapan-tahapan yang realistik dan
terukur. Oleh karena itu, pemerintah perlu melakukan kegiatan evaluasi untuk mengetahui
sejauhmana pemanfaatan TIK dalam penyelenggaraan pemerintahan. PeGI (Pemeringkatan $e$ -

DOI: 10.20422/jpk.v20i1.123 
Government di Indonesia) merupakan kegiatan yang diselenggarakan secara periodik oleh Kementerian Kominfo sejak tahun 2007 dengan tujuan untuk meningkatkan efektivitas dan efisiensi penerapan TIK di lembaga pemerintah. Dimensi penilaian PeGI mencakup aspek kebijakan, kelembagaan, infrastruktur, aplikasi, dan perencanaan. Penelitian ini bertujuan menguji secara empiris kerangka kerja (framework) PeGI yang telah digunakan untuk mengukur pemanfaatan TIK selama ini yang terdiri dari 5 (lima) dimensi dan 35 atribut penilaian. Dengan kata lain, ingin diketahui apakah framework PeGI masih relevan saat ini khususnya di tingkat kementerian mengingat perkembangan TIK yang begitu pesat dan dinamis. Metode penelitian yang digunakan adalah kuantitatif dengan pendekatan analisis faktor. Hasil penelitian menunjukkan bahwa seluruh variabel (atribut) valid dan dapat menjelaskan setiap dimensi penilaian PeGI yakni: kebijakan, kelembagaan, infrastruktur, aplikasi, dan perencanaan. Dengan demikian framework PeGI masih relevan digunakan untuk menilai penerapan $e$-Government khususnya di tingkat kementerian.

Kata kunci: PeGI, e-Government, kerangka kerja, pengujian, TIK.

\section{PENDAHULUAN}

Seiring dengan meningkatnya tuntutan masyarakat akan pelayanan publik yang berkualitas, pemerintah harus segera melakukan proses transformasi menuju $e$ Government. Pencapaian tujuan strategis $e$ Government dapat dilaksanakan melalui 6 (enam) strategi seperti yang tertuang pada Inpres No. 3 Tahun 2003, salah satunya adalah dengan melaksanakan pengembangan secara sistematik melalui tahapan-tahapan yang realistik dan terukur.

Setiap perubahan berpotensi menimbulkan ketidakpastian, oleh karena itu pengembangan e-Government perlu direncanakan dan dilaksanakan secara berkelanjutan dengan sasaran yang terukur sehingga dapat dipahami dan diikuti oleh semua pihak.

Jika ditilik perkembangan $e$ Government di tanah air dapat dikatakan masih jauh dari optimal (Furuholt \& Wahid, 2008; Jaya, 2013; Napitupulu, 2015; Napitupulu \& Sensuse, 2014). Hal ini dapat dilihat dari hasil survei Kementerian Komunikasi dan Informatika bahwa hanya ada 6 (enam) pemerintah daerah dari total 497 kabupaten/kota yang dianggap berhasil menerapkan sistem e-Government di Indonesia (Direktorat e-Government. APTIKA - KEMKOMINFO RI, 2012), sedangkan e-Government di tingkat provinsi masih dinilai kurang (Direktorat eGovernment. APTIKA - KEMKOMINFO RI, 2014). Padahal salah satu kriteria dan ukuran keberhasilan reformasi birokrasi berdasarkan Permenpan RB No. 11 Tahun 2011 adalah tersedianya e-Government pada masing-masing kementerian/lembaga dan pemerintah daerah sehingga terselenggaranya transparansi, akuntabilitas, dan standarisasi proses penyelenggaraan pemerintahan. Namun tampaknya e-Government yang tersedia pada lembaga pemerintah hanyalah merupakan formalitas kepatuhan terhadap pemenuhan kebijakan atau instruksi tersebut tanpa didukung dengan kualitas (Silalahi, Napitupulu \& Patria, 2015; Napitupulu \& Sensuse, 2014). Paradigma dan pentingnya e-Government belum dipahami dengan benar oleh aparat pemerintah bahkan ada kecenderungan hanya mengikuti tren teknologi.

Untuk melakukan evaluasi sejauh mana pemanfaatan TIK dalam penyelenggaraan pemerintahan maka Pemerintah melalui Kementerian Kominfo melaksanakan Pemeringkatan $e$ Government di Indonesia (PeGI) yang bertujuan untuk:

1. Memberikan acuan bagi pengembangan dan pemanfaatan TIK di institusi penyelenggara negara. 
2. Mendorong peningkatan pemanfaatan TIK di institusi penyelenggara negara melalui evaluasi yang utuh, seimbang, dan objektif.

3. Menghasilkan peta (potret) kondisi pemanfaatan TIK di institusi penyelenggara negara.

Dengan kata lain dengan evaluasi PeGI, lembaga pemerintah dapat mengetahui faktor-faktor apa yang menjadi kekuatan dan kelemahan dalam penerapan sistem e-Government di institusinya melalui pengukuran terhadap 5 (lima) dimensi PeGI yaitu: kebijakan, kelembagaan, infrastruktur, aplikasi, dan perencanaan. PeGI telah dilaksanakan secara periodik sejak tahun 2007 namun pada kenyataannya hingga tahun 2015 belum semua pemerintah daerah tingkat kabupaten/kota, provinsi dan kementerian di Indonesia yang diikutkan dalam penilaian PeGI. Misalnya di tingkat kementerian yang berjumlah 34 di Kabinet Kerja Jokowi 2015, baru 27 (79\%) kementerian yang dievaluasi penerapan $e$ Government-nya dan terdapat $11(41 \%)$ kementerian yang performanya dinilai kurang (Direktorat e-Government. APTIKA - KEMKOMINFO RI, 2015). Hal ini menunjukkan belum siapnya lembaga pemerintah dalam menerapkan sistem $e$ Government.

Mengingat framework PeGI telah menjadi pedoman bagi pengembangan TIK di lembaga pemerintah sejak tahun 2007 namun sangat terbatas kajian empiris terkait framework PeGI, khususnya apakah dimensi dan atribut peniliaian PeGI masih relevan digunakan hingga kini. Oleh karena itu, penelitian ini bertujuan untuk menguji framework PeGI khususnya validitas serta kesesuaian antara dimensi dan atribut penilaiannya sehingga dapat menjadi fondasi ilmiah bagi PeGI yang juga merupakan kontribusi dari penelitian ini. Lebih jauh lagi hasil dari penelitian dapat memberikan informasi bagi pemerintah khususnya di tingkat kementerian untuk mendukung keberhasilan penerapan $e$ Government.

\section{LANDASAN KONSEP}

\section{Pemeringkatan e-Government di Indonesia (PeGI)}

Seperti disebutkan sebelumnya bahwa PeGI merupakan kerangka kerja (framework) yang digunakan untuk mengukur sejauhmana pemanfaatan TIK khususnya e-Government seluruh lembaga pemerintah di Indonesia. Framework PeGI yang terdiri dari 5 (lima) dimensi dapat disajikan pada Gambar 1 sebagai berikut.

Kelima dimensi PeGI memilki bobot yang sama dalam penilaian karena semua penting, saling terkait, dan saling menunjang antara satu dengan yang lainnya. Kelima dimensi PeGI mempunyai total 35 atribut atau indikator pengukuran yang terdiri dari: dimensi kebijakan terdapat 8 atribut, 5 atribut dimensi kelembagaan, 7 atribut infrastruktur, 10 atribut dimensi aplikasi, dan 5 atribut dimensi perencanaan, seperti yang dapat disajikan pada Tabel 1 (Romayah, Suroso \& Ramadhan, 2014; Kautsarina, 2015).

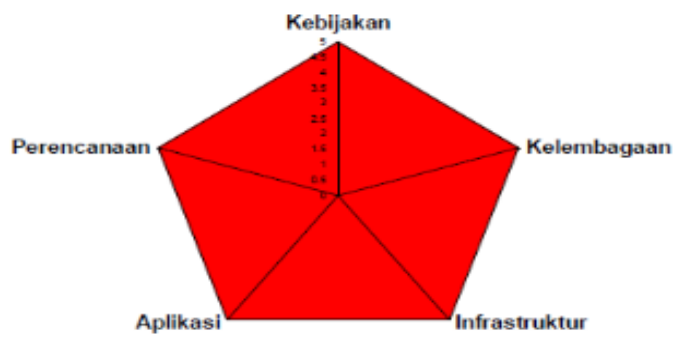

Gambar 1. Dimensi Penilaian PeGI 


\section{Tabel 1}

Dimensi dan Atribut PeGI

\begin{tabular}{|c|c|c|}
\hline No & Dimensi & (2) \\
\hline \multirow[t]{8}{*}{1} & Kebijakan & Manajemen/Proses Kebijakan TIK \\
\hline & & Visi dan Misi TIK \\
\hline & & Strategi Penerapan Kebijakan \\
\hline & & Pedoman \\
\hline & & Peraturan \\
\hline & & Keputusan Instansi \\
\hline & & Skala Prioritas TIK \\
\hline & & Evaluasi/Manajemen Risiko TIK \\
\hline \multirow[t]{5}{*}{2} & Kelembagaan & Keberadaan Organisasi \\
\hline & & Tupoksi \\
\hline & & SOP \\
\hline & & SDM \\
\hline & & Pengembangan SDM \\
\hline \multirow[t]{7}{*}{3} & Infrastruktur & Data Center \\
\hline & & Jaringan Data \\
\hline & & Keamanan \\
\hline & & Fasilitas Pendukung Infrastruktur TIK \\
\hline & & Disaster Recovery Center \\
\hline & & Pemeliharaan TIK \\
\hline & & Inventaris Peralatan TIK \\
\hline \multirow[t]{10}{*}{4} & Aplikasi & Situs Wajib (Homepage) \\
\hline & & Aplikasi Fungsional Utama (Pelayanan) \\
\hline & & Aplikasi Fungsional Utama (Administrasi dan Manajemen) \\
\hline & & Aplikasi Fungsional Utama (Legislasi) \\
\hline & & Aplikasi Fungsional Utama (Pembangunan) \\
\hline & & Aplikasi Fungsional Utama (Keuangan) \\
\hline & & Aplikasi Fungsional Utama (Kepegawaian) \\
\hline & & Manual Petunjuk Aplikasi TIK \\
\hline & & Inventaris Aplikasi TIK \\
\hline & & Interoperabilitas \\
\hline \multirow[t]{4}{*}{5} & Perencanaan & $\begin{array}{l}\text { Pengorganisasian/Fungsi } \\
\text { Sistem Perencanaan }\end{array}$ \\
\hline & & Dokumentasi Masterplan \\
\hline & & Implementasi Masterplan \\
\hline & & Anggaran/Pembiayaan \\
\hline
\end{tabular}

Berdasarkan Tabel 1, dapat dilihat bahwa dimensi kebijakan merupakan landasan utama bagi pengembangan dan implementasi e-Government yang menunjukkan arah atau tujuan, program kerja dan tata cara sebagai bukti komitmen pimpinan terhadap pelaksanaan $e$ Government. Dimensi kelembagaan berkaitan erat dengan keberadaan organisasi yang berwenang dan bertanggungjawab terhadap pengembangan dan pemanfaatan TIK. Adanya kelengkapan unit kerja dan aparaturnya serta kewenangan yang cukup diperlukan sehingga lembaga dapat menjalankan tugas dan fungsi dengan baik termasuk fungsi pengendalian dan pengawasan dalam pengembangan e-Government di 
instansinya. Dimensi infrastruktur berkaitan dengan sarana dan prasarana yang mendukung pengembangan dan pemanfaatan TIK. Kebutuhan akan pusat data, jaringan komunikasi, saluran layanan hingga fasilitas pendukung seperti AC, UPS, genset, dan ruangan khusus serta sarana pengamanan fasilitas lainnya. Dimensi aplikasi berkaitan dengan ketersediaan dan tingkat pemanfaatan piranti lunak aplikasi yang mendukung layanan e-Government secara langsung (front office) atau tidak langsung (back office). Sedangkan dimensi perencanaan berkaitan dengan tata kelola atau manajemen perencanaan TIK yang dilakukan secara terpadu dan berkesinambungan.

Adanya proses perencanaan, kajian kebutuhan, dan strategi penerapan TIK yang komprehensif tentang sasaran/tujuan, manfaat, gambaran kondisi saat ini (existing), pemilihan teknologi sampai dengan penentuan prioritas dan biaya (Fitriansyah, Budiarto \& Santoso, 2013; Romayah, Suroso \& Ramadhan, 2014).

\section{Penelitian Terkait (State of the Art)}

Penelitian sejenis yang telah dilakukan diidentifikasi untuk mengetahui perkembangan terakhir terkait dengan fokus penelitian yaitu pengujian atau validasi model PeGI. Berdasarkan studi literatur yang dilakukan dapat dijabarkan sebagai berikut:

- Penelitian sebelumnya dengan judul "Kajian Kerangka Kerja Pemeringkatan e-Government di Tingkat Kabupaten/Kotamadya" yang dilakukan oleh Ariyani (2013) bertujuan untuk melakukan analisis secara kualitatif terhadap seluruh indikator penilaian PeGI yang masih sesuai atau relevan untuk diterapkan pada tingkat kabupaten/kota, mengingat selama ini indikator PeGI digunakan untuk menilai kementerian/lembaga dan pemerintah tingkat provinsi. Penelitian ini menggunakan pendekatan kualitatif dan data dikumpulkan dengan studi literatur pada objek penelitian dengan melihat pada indikator-indikator penilaian penelitian sebelumnya serta wawancara mendalam untuk melakukan penilaian dan kecocokan pada objek penelitian. Analisis dilakukan pada dampak negatif yang mungkin terjadi jika indikator pada penilaian PeGI tidak ada. Rekomendasi penelitian ini adalah merekomendasikan indikator alternatif saluran pelayanan (e-service channel) dan indikator respon masyarakat pada dimensi aplikasi sebagai bahan pertimbangan penilaian PeGI tingkat kabupaten/kota.

- Penelitian yang dilakukan oleh Hernikawati \& Sensuse (2016) yang berjudul "Uji Validitas IndikatorIndikator Pemeringkatan EGovernment Indonesia (PeGI) Tingkat Provinsi Dengan Analisis Faktor". Penelitian ini bertujuan untuk menguji indikator-indikator dari dimensi kebijakan, kelembagaan, infrastruktur, aplikasi dan perencanaan dengan pendekatan kuantitatif yaitu analisis faktor. Data yang digunakan data sekunder hasil penilaian PeGI di tingkat provinsi. Hasil penelitian menunjukkan bahwa seluruh indikator PeGI valid kecuali indikatoraplikasi manajemen keuangan karena dianggap mandatory.

Berdasarkan dua penelitian di atas dapat dilihat bahwa untuk menguji framework atau model PeGI, penelitian pertama menggunakan pendekatan kualitatif seperti studi literatur dan wawancara sedangkan penelitian yang kedua menggunakan pendekatan kuantitatif yaitu analisis faktor.

Perbedaan penelitian sebelumnya dengan penelitian yang akan dilakukan adalah jenis data yang akan digunakan, yaitu data sekunder penilaian PeGI di tingkat kementerian (29 kementerian) untuk menguji validitas framework PeGI serta kesesuaian dimensi dan atributnya. 
Hal ini perlu dilakukan untuk mengetahui apakah model PeGI yang telah diterapkan di tingkat provinsi juga relevan jika diaplikasikan di tingkat kementerian.

Dengan kata lain, pada penelitian ini dapat dibuktikan validitas model PeGI khususnya dimensi dan atributnya secara empiris pada tingkat kementerian di Indonesia.

\section{METODE PENELITIAN}

Metode yang digunakan dalam penelitian ini adalah metode kuantitatif dengan pendekatan analisis faktor. Data yang digunakan adalah data sekunder hasil penilaian Pemeringkatan e-Government di Indonesia (PeGI) di tingkat kementerian yakni sejumlah 29 kementerian.

Penilaian PeGI di tingkat kementerian dilakukan oleh 6 (enam) orang expert sebagai asesor PeGI sehingga total data berjumlah 174 yang akan diolah dan dimasukkan dalam tahap analisis.

Instrumen dalam penilaian $e$ Government menggunakan skala likert 1 sampai dengan 4, dengan 1 menunjukkan sangat kurang, 2 menunjukkan kurang, 3 menunjukkan nilai baik, dan 4 menunjukkan sangat baik. Nilai total ratarata seluruh dimensi menunjukkan kondisi penerapan e-Government dapat dikategorikan sebagai berikut (Fitriansyah, Budiarto \& Santoso, 2013).

- Nilai 1.0 sampai dengan 1.49 (sangat kurang) dengan indikator tidak ada sama sekali atau sangat kurang dari segi jumlah dan kualitas.

- Nilai 1,5 sampai dengan 2,49 (kurang) dengan indikator sudah ada namun masih perlu ditambah dari segi jumlah dan ditingkatkan secara kualitas.

- Nilai 2,5 sampai dengan 3,49 (baik) dengan indikator berjumlah dan berkualitas cukup baik dan dapat dilihat membawa dampak positif pada pemanfaatan e-Government namun masih diperlukan perbaikan-perbaikan untuk menjaga kelangsungan implementasi e-Government pada masa yang akan datang.

- Nilai 3,5 sampai dengan 4,0 (sangat baik) di mana indikator baik dari segi jumlah maupun kualitas sangat baik. Dampak pada penerapan $e$ Government terlihat sangat nyata dan kesiapan untuk terus dikembangkan pada masa yang akan datang sudah terlihat jelas.

Pendekatan analisis faktor digunakan untuk menganalisis atau menguji apakah kerangka kerja PeGI masih relevan untuk digunakan menilai penerapan $e$ Government di Indonesia khususnya di tingkat kementerian. Dengan kata lain, validitas dari setiap dimensi dan atribut PeGI akan dapat dibuktikan secara empiris.

Hal ini sesuai dengan tujuan atau kegunaan dari pendekatan analisis faktor yakni dapat menemukan hubungan (interrelationship) antarsejumlah besar variabel (konstruk) yang saling independen satu dengan yang lain sehingga bisa dibuat satu atau beberapa kumpulan variabel atau dimensi (faktor) yang lebih sedikit jumlahnya dari variabel awal atau dikenal dengan data reduction (Santoso, 2010; Williams, Onsman \& Brown, 2010).

Dengan analisis faktor dapat dibangun hipotesis atau teori baru berdasarkan dimensi yang dibangun antara konstruk dan variabel laten. Analisis faktor juga menyediakan bukti empiris dari konstruk yang membentuk variabel laten (construct validity) berdasarkan hasil pengukuran dalam rangka untuk menguji suatu hipotesis atau teori (theoretical construct) dalam penelitian (Santoso, 2010; Williams, Onsman \& Brown, 2010).

Dengan kata lain, pendekatan analisis faktor yang digunakan dapat diketahui hubungan diantara atribut atau indikator terhadap dimensi yang ada pada PeGI. Pengolahan dan analisis data dilakukan dengan alat bantu software statistik IBM SPSS ver 22. 


\section{HASIL PENELITIAN DAN PEMBAHASAN}

Jumlah data yang diolah dan dianalisis dengan pendekatan analisis faktor adalah 174 sampel hasil pengukuran. Jumlah ukuran sampel tersebut dianggap sudah memadai dan memenuhi persyaratan Cattell (1978) merekomendasikan model ratio $(\mathrm{N} / \mathrm{p})$ antara jumlah sampel $(\mathrm{N})$ dan jumlah variabel yakni 3 hingga 6 sampel per variabel $(3 / 1-6 / 1)$. Pada penelitian ini terdapat 35 variabel pengukuran dan 174 sampel sehingga telah memenuhi rekomendasi yang diberikan yakni mendekati ratio 5/1. Setelah jumlah sampel dianggap memadai.

Selanjutnya adalah uji kelayakan variabel. Namun sebelumnya data hasil kuesioner diukur koefisien reliabilitasnya dengan Cronbach Alpha di mana diperoleh angka sebesar 0.959. Hal ini menunjukkan instrumen yang digunakan reliabel karena memenuhi persyaratan yakni di atas 0.80 (Cronbach, 1951). Pengujian kelayakan variabel dilakukan berdasarkan nilai KMO (Kaiser-Meyer-Olkin) sebagai berikut.

- Nilai KMO berkisar antara 0 sampai dengan 1 yang menunjukkan apakah variabel atau sampel layak atau tidak untuk bisa dianalisis lebih lanjut. Apabila nilai KMO sama dan lebih besar dari setengah dan dengan nilai signifikan ( $\mathrm{sig}$ ) atau peluang (p) lebih kecil dari setengah maka dinyatakan variabel atau sampel sudah layak untuk dianalisis lebih lanjut dalam analisis faktor.

- Hipotesis untuk signifikansi adalah:

$\mathrm{H}_{0}=$ Sampel (variabel) belum memadai untuk dianalisis lebih lanjut.

$\mathrm{H}_{1}=$ Sampel (variabel) telah memadai untuk dianalisis lebih lanjut.

- Kriteria dengan melihat probabilitas:

Angka sig > 0.05 maka $\mathrm{H}_{0}$ diterima.

Angka sig $<0.05$ maka $\mathrm{H}_{0}$ ditolak.

\section{Dimensi Kebijakan}

Hasil dari pengujian kelayakan variabel untuk dimensi kebijakan dapat ditunjukkan sebagai berikut:

Dari Tabel 2 dapat dilihat bahwa nilai KMO dan Bartlett's Test yang diperoleh adalah 0.888 dengan signifikansi 0.000 . Hal ini beimplikasi Ho ditolak yang berarti bahwa sampel atau variabel telah layak atau memadai untuk dianalisis lebih lanjut dalam analisis faktor. Oleh karena nilai tersebut sudah di atas 0.5 dan signifikansi jauh di bawah $0.05(0.000<0.05)$.

Setelah sampel telah memenuhi persyaratan maka berikutnya adalah melihat total variance yang menunjukkan jumlah faktor yang terbentuk berdasarkan angka eigen values seperti yang disajikan pada Tabel 3.

Jumlah faktor yang terbentuk dapat menjelaskan variabilitas seluruh variabel yang digunakan dengan kriteria angka eigen values di bawah 1 tidak digunakan dalam menghitung jumlah faktor yang terbentuk.

Berdasarkan Tabel 3, dapat dilihat faktor yang terbentuk (cetak tebal) adalah hanya 1 faktor (component) karena mempunyai eigen values di atas 1 yakni 4.533 sedangkan 7 faktor (component) yang lain angka eigen values-nya di bawah satu. Hal ini juga menunjukkan pada tahap ini ada pengelompokkan sejumlah variabel ke faktor tertentu karena adanya kemiripan atau kesamaan ciri variabel-variabel tertentu. Dengan demikian satu faktor yang terbentuk adalah jumlah yang paling optimal di mana faktor tersebut dapat menjelaskan variabilitas sebesar 56.909\% dari keseluruhan variabel. Hal ini membuktikan bahwa 8 (delapan) variabel (atribut) yang digunakan untuk menilai sudah sesuai menjelaskan satu faktor yakni kebijakan.

Selanjutnya adalah melihat korelasi antara variabel yang ada dengan faktor yang terbentuk yaitu berdasarkan nilai faktor loading. BerdasarkanOsborne \& Costello (2005) bahwa struktur faktor telah murni atau fit jika faktor loading lebih 
besar dari 0.3 yang menunjukkan faktor loading memiliki nilai standar yang cukup tinggi dan mengindikasikan variabel tersebut mempunyai korelasi yang kuat dengan faktor yang terbentuk (convergent validity). Senada dengan itu, Hair, Anderson, Tatham, et al.(1998) menyarankan bahwa faktor loading dari item (variabel) $>0.3$ dianggap signifikan, faktor item $>0.4$ adalah lebih penting dan faktor loading item $>0.5$ dianggap sangat signifikan. Dalam penelitian ini akan digunakan nilai cut-off faktor loading yaitu 0.5 sehingga diperoleh faktor loading yang tinggi (strong loading factor).

Berdasarkan Tabel 4 di bawah dapat dilihat seluruh variabel (atribut) pengukuran mempunyai nilai faktor loading diatas $0.5 \quad(>0.5)$ yang berarti semua variabel memiliki korelasi yang kuat dan signifikan terhadap faktor yang terbentuk yaitu kebijakan.

Tabel 2

KMO and Bartlett's Test Dimensi Kebijakan

Kaiser-Meyer-Olkin Measure of Sampling Adequacy

Df

Tabel 3

Total Variance Explained Dimensi Kebijakan

\begin{tabular}{cccc}
\hline & \multicolumn{3}{c}{ Initial EigenValues } \\
\cline { 2 - 4 } Component & Total & \% of Variance & Cumulative \% \\
\hline 1 & 4.553 & 56.909 & 56.909 \\
2 & .814 & 10.180 & 67.088 \\
3 & .704 & 8.803 & 75.891 \\
4 & .572 & 7.155 & 83.047 \\
5 & .454 & 5.674 & 88.720 \\
6 & .370 & 4.627 & 93.347 \\
7 & .298 & 3.725 & 97.073 \\
8 & .234 & 2.927 & 100.000 \\
\hline
\end{tabular}

Tabel 4

Component Matrix ${ }^{\text {a }}$ Dimensi Kebijakan

\begin{tabular}{lc}
\hline & Component \\
\cline { 2 - 2 } & 1 \\
\hline Manajemen/Proses Kebijakan TIK & .789 \\
Visi dan Misi TIK & .585 \\
Strategi Penerapan Kebijakan & .814 \\
Pedoman & .788 \\
Peraturan & .716 \\
Keputusan Instansi & .776 \\
Skala Prioritas TIK & .834 \\
Evaluasi/Manajemen Risiko TIK & .703
\end{tabular}




\section{Dimensi Kelembagaan}

Nilai KMO dan Bartlett's Test yang dimiliki oleh dimensi kelembagaan yaitu 0.890 dengan signifikansi 0.000 seperti yang disajikan pada Tabel 5. Hal ini berimplikasi Ho juga ditolak atau $\mathrm{H} 1$ diterima yang berarti bahwa variabel telah layak atau memadai untuk dianalisis lebih lanjut dalam analisis faktor karena nilai KMO sudah jauh di atas 0.5 dan signifikansi juga di bawah $0.05(0.000<$ 0.05).

Selanjutnya adalah melihat jumlah faktor yang terbentuk dengan analisis totalvariance explained berdasarkan angka eigen values. Dari Tabel 6 dapat dilihat bahwa faktor yang terbentuk adalah juga hanya satu faktor (component) karena faktor tersebut memiliki eigen values di atas satu yakni 4.072 sedangkan 6 (enam) faktor (component) yang lain angka eigen values-nya di bawah satu. Faktor yang terbentuk tersebut dapat menjelaskan variabilitas sebesar $58.171 \%$ dari keseluruhan variabel pengukuran. Hal ini berarti membuktikan bahwa 7 (tujuh) variabel (atribut) yang digunakan sudah sesuai untuk menjelaskan satu faktor yakni kelembagaan.

Berdasarkan Tabel 7 dapat dilihat bahwa seluruh variabel (atribut) pengukuran juga mempunyai nilai faktor loading di atas $0.5(>0.5)$ dengan rentang antara 0.724 sampai dengan 0.813 . Hal ini berarti semua variabel memiliki korelasi yang kuat dan signifikan terhadap faktor yang terbentuk yaitu kelembagaan.

Tabel 5

KMO and Bartlett's Test Dimensi Kelembagaan

\begin{tabular}{lrr}
\hline Kaiser-Meyer-Olkin Measure of Sampling Adequacy & $\mathbf{. 8 9 0}$ \\
\hline Bartlett's Test of Sphericity & Approx. Chi-Square & 509.174 \\
& df & 21 \\
& Sig. & .000 \\
\hline
\end{tabular}

Tabel 6

Total Variance Explained Dimensi Kelembagaan

\begin{tabular}{cccc}
\hline & \multicolumn{3}{c}{ Initial Eigen Values } \\
\cline { 2 - 4 } Component & Total & \% of Variance & Cumulative \% \\
\hline 1 & 4.072 & 58.171 & 58.171 \\
2 & .775 & 11.078 & 69.249 \\
3 & .619 & 8.837 & 78.086 \\
4 & .449 & 6.414 & 84.500 \\
5 & .422 & 6.031 & 90.531 \\
6 & .351 & 5.009 & 95.540 \\
7 & .312 & 4.460 & 100.000 \\
\hline
\end{tabular}

Tabel 7

Component Matrix ${ }^{a}$.Dimensi Kelembagaan

\begin{tabular}{lc}
\hline & Component \\
\cline { 2 - 2 } & 1 \\
\hline Keberadaan Organisasi & .779 \\
Tupoksi & .813 \\
SOP & .732 \\
SDM & .724 \\
Pengembangan SDM & .758 \\
\hline
\end{tabular}




\section{Dimensi Infrastruktur}

Hasil pengujian kelayakan variabel berdasarkan nilai KMO (Kaiser-MeyerOlkin) dan Bartlett's Test dari dimensi infrastruktur dapat dijelaskan pada Tabel 8 sebagai berikut: nilai KMO pada Tabel 8 menunjukkan angka 0.709 yang berarti nilai tersebut lebih besar dari $0.5(>0.5)$ dengan signfikansi untuk Bartlett's Test yaitu 0.000 yang berada di bawah 0.05 $(<0.05)$. Hal ini menunjukkan bahwa sampel atau variabel dianggap telah layak untuk dilanjutkan dalam tahap analisis faktor berikutnya.

Dari Tabel 9, dapat dilihat bahwa jumlah faktor yang terbentuk adalah satu faktor dengan eigen values sebesar 2.903 di mana faktor yang terbentuk tersebut dapat menjelaskan variabilitas sebesar $58.063 \%$ dari keseluruhan variabel. Hal ini berarti membuktikan bahwa 5 (lima) variabel (atribut) yang digunakan sudah valid untuk menjelaskan satu faktor yakni infrastruktur.

Berdasarkan Tabel 10, di atas dapat ditunjukkan bahwa seluruh variabel (atribut) pengukuran juga mempunyai nilai faktor loading di atas 0.5 (>0.5) dengan rentang antara 0.657 sampai dengan 0.843 . Hal ini berarti semua variabel memiliki korelasi yang kuat dan signifikan terhadap faktor yang terbentuk yaitu infrastruktur. Kesesuaian antara variabel (atribut) dan dimensi PeGI yakni infrastruktur sudah terbukti secara empiris.

Tabel 8

KMO and Bartlett's Test Dimensi Infrastruktur

\begin{tabular}{|c|c|c|}
\hline \multicolumn{2}{|c|}{ Kaiser-Meyer-Olkin Measure of Sampling Adequacy } & .709 \\
\hline \multirow[t]{3}{*}{ Bartlett's Test of Sphericity } & Approx. Chi-Square & 318.529 \\
\hline & df & 10 \\
\hline & Sig. & .000 \\
\hline
\end{tabular}

Tabel 9

Total Variance Explained Dimensi Infrastruktur

\begin{tabular}{cccc}
\hline & \multicolumn{3}{c}{ Initial Eigen Values } \\
\cline { 2 - 4 } Component & Total & \% of Variance & Cumulative \% \\
\hline 1 & 2.903 & 58.063 & 58.063 \\
2 & .848 & 16.955 & 75.018 \\
3 & .640 & 12.805 & 87.822 \\
4 & .385 & 7.706 & 95.529 \\
5 & .224 & 4.471 & 100.000 \\
\hline
\end{tabular}

Tabel 10

Component Matrix ${ }^{\text {a }}$ Dimensi Infrastruktur

\begin{tabular}{lc}
\hline & Component \\
\cline { 2 - 2 } Data Center & 1 \\
Jaringan Data & .764 \\
Keamanan & .786 \\
Fasilitas Pendukung Infrastruktur TIK & .801 \\
Disaster Recovery Center & .843 \\
Pemeliharaan TIK & .686 \\
Inventaris Peralatan TIK & .784 \\
\hline
\end{tabular}




\section{Dimensi Aplikasi}

Nilai KMO untuk sampel dimensi aplikasi berdasarkan Tabel 11 yaitu 0.847 dengan signifikansi Bartlett's Test sebesar 0.000. Hal ini berimplikasi $\mathrm{H}_{0}$ juga ditolak bahwa variabel telah layak atau memadai untuk dianalisis lebih lanjut dalam analisis faktor karena nilai KMO berada diatas 0.5 dan signifikansi di bawah $0.05(0.000<$ 0.05). Dengan kata lain sampel atau variabel telah memenuhi persyaratan analisis faktor.

Pada Tabel 12, terlihat bahwa jumlah faktor yang terbentuk adalah 2 (dua) faktor dengan nilai eigen values faktor pertama yakni 4.703 dan faktor kedua sebesar 1.380. Faktor pertama dapat menjelaskan variabilitas sebesar $47.034 \%$ sedangkan faktor kedua dapat menjelaskan variabilitas sebesar $13.800 \%$ dari seluruh variabel. Hasil analisis ini berlawanan dengan framework PeGI di mana hanya ada satu faktor saja yakni aplikasi untuk 10 variabel (atribut). Namun jika dilihat faktor yang terbentuk pada Tabel 13, dapat dikatakan bahwa struktur faktornya belum murni atau fit karena masih ada item (variabel) yang cross loading (satu item memiliki faktor loading yang tinggi pada dua atau lebih faktor yang terbentuk) seperti pada variabel "Aplikasi Fungsional Utama (Legislasi)" dan variabel "Aplikasi Fungsional Utama (Pelayanan)".

Jika terjadi hal yang demikian, berdasarkan Osborne \& Costello (2005) untuk memurnikan analisis faktor dapat dilakukan dengan cara memanipulasi jumlah faktor. Berdasarkan saran Osborne \& Costello (2005) maka dilakukan pengurangan jumlah faktor dari dua faktor menjadi satu faktor sehingga memperoleh struktur faktor yang murni atau fit dimana tidak terdapat lagi cross loading item seperti pada Tabel 14.

Pada Tabel 14, dapat dilihat bahwa setiap variabel (atribut) pengukuran juga mempunyai nilai faktor loading di atas 0.5 $(>0.5)$ dengan rentang antara 0.555 sampai dengan 0.774. Hal ini menunjukkan semua variabel memiliki korelasi yang kuat dan signifikan terhadap faktor yang terbentuk yaitu aplikasi. Dengan kata lain dapat dikatakan bahwa seluruh variabel (atribut) juga sudah valid untuk mengukur aspek atau dimensi aplikasi pada sistem $e$ Government. Kesesuaian antara variabel (atribut) dan dimensi dapat dibuktikan secara empiris.

Tabel 11

KMO and Bartlett's Test Dimensi Aplikasi

\begin{tabular}{llr}
\hline Kaiser-Meyer-Olkin Measure of Sampling Adequacy & $\mathbf{. 8 6 8}$ \\
\hline Bartlett's Test of Sphericity & Approx. Chi-Square & 694.616 \\
& df & 45 \\
& Sig. & .000 \\
\hline
\end{tabular}

Tabel 12

Total Variance Explained Dimensi Aplikasi

\begin{tabular}{cccc}
\hline & \multicolumn{3}{c}{ Initial Eigen Values } \\
\cline { 2 - 4 } Component & Total & \% of Variance & Cumulative \% \\
\hline 1 & 4.703 & 47.034 & 47.034 \\
2 & 1.380 & 13.800 & 60.834 \\
3 & .876 & 8.756 & 69.590 \\
4 & .633 & 6.327 & 75.917 \\
5 & .558 & 5.583 & 81.500 \\
6 & .470 & 4.703 & 86.202 \\
7 & .423 & 4.228 & 90.430 \\
8 & .375 & 3.749 & 94.179 \\
9 & .343 & 3.433 & 97.612 \\
10 & .239 & 2.388 & 100.000 \\
\hline
\end{tabular}


Tabel 13

Rotated Component Matrix ${ }^{\mathrm{a}}$

\begin{tabular}{lcc}
\hline & \multicolumn{2}{c}{ Component } \\
\cline { 2 - 3 } & 1 & 2 \\
\hline Situs Wajib (Homepage) & .652 & .274 \\
Aplikasi Fungsional Utama (Pelayanan) & .461 & .488 \\
Aplikasi Fungsional Utama (Administrasi dan Manajemen) & .283 & .695 \\
& & \\
Aplikasi Fungsional Utama (Legislasi) & .544 & .520 \\
Aplikasi Fungsional Utama (Pembangunan) & .408 & .652 \\
Aplikasi Fungsional Utama (Keuangan) & .128 & .806 \\
Aplikasi Fungsional Utama (Kepegawaian) & .026 & .802 \\
Manual Petunjuk Aplikasi TIK & .830 & .234 \\
Inventaris Aplikasi TIK & .788 & .113 \\
Interoperabilitas & .844 & .114 \\
\hline
\end{tabular}

Tabel 14

Component Matrix $x^{\mathrm{a}}$ Dimensi Aplikasi

\begin{tabular}{lc}
\hline & Component \\
\cline { 2 - 2 } Situs Wajib (Homepage) & 1 \\
Aplikasi Fungsional Utama (Pelayanan) & .668 \\
Aplikasi Fungsional Utama (Administrasi dan Manajemen) & .669 \\
Aplikasi Fungsional Utama (Legislasi) & .675 \\
Aplikasi Fungsional Utama (Pembangunan) & .752 \\
& .739 \\
Aplikasi Fungsional Utama (Keuangan) & .634 \\
Aplikasi Fungsional Utama (Kepegawaian) & .555 \\
Manual Petunjuk Aplikasi TIK & .774 \\
Inventaris Aplikasi TIK & .662 \\
Interoperabilitas & .704 \\
\hline
\end{tabular}

\section{Dimensi Perencanaan}

Hasil pengujian kelayakan variabel berdasarkan nilai KMO (Kaiser-MeyerOlkin) dan signifikansi Bartlett's Test dapat dijelaskan pada Tabel 15.

Nilai KMO pada Tabel 15, menunjukkan angka 0.847 yang berarti nilai tersebut lebih besar dari $0.5(>0.5)$ dengan signfikansi untuk Bartlett's Test yaitu 0.000 yang berada di bawah 0.05 $(<0.05)$. Hal ini berarti bahwa sampel atau variabel dianggap telah layak untuk dilanjutkan dalam tahap analisis faktor berikutnya.

Pada Tabel 16, dapat dilihat bahwa jumlah faktor yang terbentuk adalah hanya satu faktor dengan angka eigen values
3.351. Faktor yang terbentuk dapat menjelaskan varians $67.015 \%$ dari keseluruhan variabel. Artinya terdapat $32.985 \%$ varians yang dijelaskan oleh variabel di luar penelitian.

Pada Tabel 17, di atas dapat dilihat bahwa seluruh variabel (atribut) memiliki nilai faktor loading di atas $0.5(>0.5)$ yakni dengan rentang antara $0.681 \mathrm{~s} / \mathrm{d} 0.890$. Hal ini berarti seluruh variabel memiliki korelasi yang kuat dan signifikan terhadap faktor yang terbentuk yaitu perencanaan.

Dengan kata lain dapat dikatakan bahwa semua variabel (atribut) juga sudah valid untuk mengukur dimensi perencanaan pada PeGI. Variabel (atribut) dan dimensi PeGI yakni perencanaan secara empiris sudah terbukti masih relevan dan valid. 
Tabel 15

KMO and Bartlett's Test Dimensi Perencanaan

Kaiser-Meyer-Olkin Measure of Sampling Adequacy

Bartlett's Test of Sphericity

Approx. Chi-Square

420.633

df

Sig.

Tabel 16

Total Variance Explained Dimensi Perencanaan

\begin{tabular}{cccc}
\hline & \multicolumn{3}{c}{ Initial Eigen Values } \\
\cline { 2 - 4 } Component & Total & \% of Variance & Cumulative \% \\
\hline 1 & 3.351 & 67.015 & 67.015 \\
2 & .658 & 13.152 & 80.167 \\
3 & .454 & 9.073 & 89.240 \\
4 & .297 & 5.933 & 95.174 \\
5 & .241 & 4.826 & 100.000 \\
\hline
\end{tabular}

Tabel 17

Component Matrix ${ }^{\mathrm{a}}$ Dimensi Perencanaan

\begin{tabular}{lc}
\hline & Component \\
\cline { 2 - 2 } & 1 \\
\hline Pengorganisasian/Fungsi & .791 \\
Sistem Perencanaan & .890 \\
Dokumentasi Masterplan & .844 \\
Implementasi Masterplan & .870 \\
Anggaran/Pembiayaan & .681 \\
\hline
\end{tabular}

Tabel 18

Total Variance Explained per Dimensi

\begin{tabular}{ccc}
\hline No & Dimensi & \% of Variance \\
\hline 1 & Kebijakan & 56.909 \\
2 & Kelembagaan & 58.171 \\
3 & Infrastruktur & 58.063 \\
4 & Aplikasi & 60.834 \\
5 & Perencanaan & 67.015 \\
\hline
\end{tabular}

\section{Implikasi Teoretis dan Praktis}

Berdasarkan hasil analisis yang diperoleh untuk setiap dimensi yang ada pada PeGI yaitu dimensi kebijakan, kelembagaan, infrastruktur, aplikasi, dan perencanaan dapat dibuktikan secara empiris bahwa setiap atribut (variabel) dapat dikatakan dapat merepresentasikan atau menjelaskan dimensinya masingmasing. Hal ini dapat ditunjukkan dari hasil analisis yakni berdasarkan jumlah faktor yang terbentuk (eigenvalues) dan loading faktor yang kuat (>0.5). Hasil analisis ini membuktikan bahwa model PeGI masih relevan digunakan untuk mengukur implementasi e-Government di tingkat 
kementerian, seperti yang sudah dilakukan oleh Hernikawati \& Sensuse (2016) di tingkat provinsi.

Namun jika dikaji lebih dalam dari setiap faktor yang terbentuk ternyata masih ada variasi variabel atau atribut yang tidak terdapat pada model PeGI dan memerlukan penelitian lebih lanjut. Hal ini dapat terlihat dari total variance explained dari tiap dimensinya seperti yang dapat disajikan pada Tabel 18

Berdasarkan Tabel 18, dapat ditunjukkan untuk dimensi kebijakan, sebesar 56.909\% variasinya dapat dijelaskan oleh atribut atau variabelnya, sisanya sebesar $43.091 \%$ dijelaskan oleh varaibel lain yang belum terdapat pada model PeGI.

Demikan juga untuk dimensi kelembagaan, variasinya hanya dapat dijelaskan oleh variabelnya sebesar $58.171 \%$ sedangkan sisanya sebesar $41.829 \%$ dijelaskan oleh variabel lain diluar model PeGI. Untuk dimensi infrastruktur, variasinya sebesar $58.063 \%$ dapat dijelaskan oleh seluruh variabelnya namun sisanya sebesar $41.937 \%$ dijelaskan oleh variabel lain yang tidak terdapat dalam model.

Untuk dimensi aplikasi, sebesar $60.834 \%$ dapat dijelaskan oleh variabelnya sedangkan sisanya $39.166 \%$ juga dijelaskan oleh variabel lain di luar model. Untuk dimensi perencanaan, variasinya sebesar $67.015 \%$ dapat dijelaskan oleh variabelnya sedangkan sisanya sebesar $32.985 \%$ dapat dijelaskan oleh variabel lain di luar model PeGI. Dengan demikian dapat dikatakan bahwa perlu studi lebih lanjut untuk mengidentifikasi atribut/variabel lainnya yang dapat menjelaskan model pengukuran PeGI secara utuh.

Namun secara praktis, penelitian ini telah berhasil membuktikan bahwa model PeGI terutama atribut atau variabel yang dijadikan indikator pengukuran adalah valid dan reliabel secara empiris sehingga masih relevan untuk digunakan hingga saat ini khususnya untuk pemeringkatan $e$ -
Government pada tingkat kementerian di Indonesia.

\section{PENUTUP}

\section{Simpulan}

Berdasarkan hasil penelitian yang telah dilakukan dapat ditarik beberapa simpulan yaitu dengan pendekatan kuantitatif analisis faktor diperoleh bahwa untuk setiap dimensi PeGI yakni kebijakan, kelembagaan, infrastruktur, aplikasi, dan perencanaan mempunyai variabel (atribut) yang valid dan reliabel berdasarkan nilai faktor loading yang tinggi dan koefisien reliabilitas Cronbach Alpha. Faktor atau dimensi yang terbentuk juga sudah sesuai dengan model PeGI. Dengan kata lain, seluruh variabel yang diukur dapat menjelaskan atau merepresentasikan dimensi pengukuran PeGI. Penelitian ini memberikan kontribusi ilmiah untuk membuktikan secara empiris validitas model PeGI khususnya pada tingkat kementerian di Indonesia. Hal ini berarti atribut dan dimensi PeGI masih relevan digunakan untuk menilai penerapan $e$ Government di Indonesia khususnya tingkat kementerian.

\section{Saran}

Saran penelitian dapat dilakukan penelitian lebih lanjut untuk mengidentifikasi atribut atau variabel pengukuran lainnya yang belum terdapat pada model PeGI ditinjau dari total variasinya yang tergolong rendah.

Selain itu perlu dilakukan pengujian model PeGI lebih luas lagi misalnya untuk pemerintah daerah (Pemda) tingkat kabupaten/kota. Hal ini dikarenakan keterbatasan data yang dimiliki pada penelitian ini yakni hanya di tingkat kementerian. Dengan demikian pada gilirannya dapat mendukung standarisasi dan pemanfaatan secara luas model PeGI di Indonesia. 


\section{DAFTAR PUSTAKA}

Ariyani, P.F. (2013) KAJIAN KERANGKA KERJA PEMERINGKATAN EGOVERNMENT DI TINGKAT KABUPATEN/KOTAMADYA. BIT. [Online] 10 (1), 41-49. Available from: http://riset.budiluhur.ac.id/publikasiilmiah/bit/vol-10-no-1/.

Cattell, R.B. (1978) The Scientific Use of Factor Analysis in Behavioral and Life Sciences. New York, Plenum.

Cronbach, L.J. (1951) Coefficient alpha and the internal structure of tests. Psychometrika. [Online] 16 (3), 297334. Available from: doi:10.1007/BF02310555.

Direktorat e-Government. APTIKA KEMKOMINFO RI (2014) PeGI Tingkat Provinsi pada Tahun 2014. [Online]. 2014. Pemeringkatan eGovernment Indonesia (PeGI). Available from:

http://pegi.layanan.go.id/download/tabel _pegi_2014/HASIL PROVINSI 2014.bmp.

Direktorat e-Government. APTIKA KEMKOMINFO RI (2015) PeGI Tingkat Provinsi Tahun 2015. [Online]. 2015. Pemeringkatan e-Government Indonesia (PeGI). Available from: http://pegi.layanan.go.id/download/tabel _pegi_2015/2015_PROVINSI.PNG.

Direktorat e-Government. APTIKA KEMKOMINFO RI (2012) Tabel PeGI 2012. [Online]. 2012. Pemeringkatan eGovernment Indonesia (PeGI). Available from: http://pegi.layanan.go.id/tabelhasil-pegi-4/.

Fitriansyah, A., Budiarto, H. \& Santoso, J. (2013) Metode Pemeringkatan eGovernment Indonesia (PeGI) Untuk Audit Tata Kelola Teknologi Informasi. In: Seminar Nasional Sistem Informasi Indonesia (SESINDO) 2013. 2013 pp. 10-20.

Furuholt, B. \& Wahid, F. (2008) E-Government Challenges and the Role of Political Leadership in Indonesia: The Case of Sragen. In: Proceedings of the 41st Annual Hawaii International Conference on System Sciences (HICSS 2008). [Online]. January 2008 IEEE. p. 411.
Available from: doi:10.1109/HICSS.2008.134.

Hair, J.F., Anderson, R.E., Tatham, R.L. \& Black, W.C. (1998) Multivariate Data Analysis with Readings. 5th edition. New Jersey, Prentice-Hill.

Hernikawati, D. \& Sensuse, D.I. (2016) Uji Validitas Indikator-Indikator Pemeringkatan E-Government Indonesia (Pegi) Tingkat Provinsi Dengan Analisis Faktor. Jurnal Penelitian Pos dan informatika. [Online] 6 (1), 1-18. Available from: doi:10.17933/jppi.2016.060101.

Jaya, S. (2013) Implementasi Dan Perkembangan E-Government di Indonesia. Jurnal Informatika Multimedia (JIM) STIMED NUSA PALAPA. [Online] 2 (1), 37-52. Available from: http://jim.stimednp.ac.id/wpcontent/uploads/2014/03/IMPLEMENT ASI-DAN-PERKEMBANGAN-EGOVERNMENT.pdf.

Kautsarina (2015) Kajian Inventarisasi Aset Teknologi Informasi dan Komunikasi di Instansi Pemerintah. Jurnal Penelitian dan Pengembangan Komunikasi dan Informatika. 6 (1), 49-58.

Napitupulu, D. (2015) Kajian Faktor Sukses Implementasi E-Government. Studi Kasus: Pemerintah Kota Bogor. Jurnal Sistem Informasi. 5 (3), 229-236.

Napitupulu, D. \& Sensuse, D.I. (2014) The Critical Success Factors Study for eGovernment Implementation. International Journal of Computer Applications. [Online] 89 (16), 23-32. Available from: https://pdfs.semanticscholar.org/7e $84 / \mathrm{d} 9$ c75dba5d462c2b536818f5142bf2edd00 0. pdf.

Osborne, J.W. \& Costello, A.B. (2005) Best Practices in Exploratory Factor Analysis: Four Recommendations for Getting the Most From Your Analysis. Practical Assessment, Research \& Evaluation. 10 (7), 1-9.

Romayah, S., Suroso, A.I. \& Ramadhan, A. (2014) Evaluasi Implementasi Egovernment di Instansi XYZ. Jurnal Aplikasi Manajemen. [Online] 12 (4), 612-620. Available from: http://www.jurnaljam.ub.ac.id/index.php /jam/article/view/711. 
Santoso, S. (2010) Statistik Multivariat. Jakarta, PT. Gramedia.

Silalahi, M., Napitupulu, D. \& Patria, G. (2015) Kajian Konsep Dan Kondisi eGovernment di Indonesia. JUPITER . [Online] 1 (1), 10-16. Available from: http://id.portalgaruda.org/?ref=browse \& mod=viewarticle \&article $=356188$.
Williams, B., Onsman, A. \& Brown, T. (2010) Exploratory factor analysis: A five-step guide for novices. Journal of Emergency Primary Health Care. [Online] 8 (3), 113. Available from: https://ajp.paramedics.org/index.php/ajp /article/view/93. 